\title{
ENTRE A NORMA E A CRÍTICA: O RELATO DE SCHOLASTIQUE \\ MUKASONGA COMO REIVINDICAÇÃO POR RECONHECIMENTO
}

\author{
BETWEEN NORM AND CRITIQUE: THE ACCOUNT OF \\ SCHOLASTIQUE MUKASONGA AS A CLAIM FOR RECOGNITION
}

\author{
Lucas Demingos (UFRGS) \\ lucasdemingos@gmail.com \\ Maria Petrucci (UFRGS) \\ amariapetrucci@gmail.com
}

\begin{abstract}
RESUMO: O presente artigo busca refletir a respeito dos possíveis vínculos entre estética, política e ética na obra A mulher de pés descalços (2018), de Scholastique Mukasonga, no que tange à reivindicação por reconhecimento. Lançamos mão do conceito rancièreano de política para analisar os desdobramentos da narrativa da autora, que embaralha os termos da partilha do sensivel ao relatar e, assim, humanizar um povo desapossado e silenciado. Investigamos, ainda, as relações entre o estatuto conferido aos tutsis de sujeitos passíveis de violência sistemática e extermínio sancionado pelo Estado, e a urgência ética do relato de si dado pela narradora de Mukasonga a partir da história de sua mãe, que abraça suas próprias opacidades e limites, assumindo desde sempre sua vulnerabilidade e dependência em uma sociabilidade primária.
\end{abstract}

PALAVRAS-CHAVE: reconhecimento; literatura; Scholastique Mukasonga; Judith Butler.

\begin{abstract}
This paper seeks to reflect on the possible links between aesthetics, politics and ethics in Scholastique Mukasonga's The Barefoot Woman (2018), in regards to its elaboration on a claim for recognition. We make use of Jacques Rancière's concept of politics to analyze the unfolding of the author's narrative, which shuffles the terms of the distribution of the sensible as it makes an account of and thus humanizes a dispossessed and silenced people. We also investigate the relationship between the status given to Tutsis as subjects liable to systematic violence and state-sanctioned extermination, and the ethical urgency of the account given by Mukasonga's narrator through her mother's story, which embraces its own opacities and limits, assuming since the beginning its vulnerability and dependence on a primary sociability.
\end{abstract}


KEYWORDS: recognition; literature; Scholastique Mukasonga; Judith Butler.

\section{Introdução}

Seria possível refletir sobre os entrelaçamentos entre narrativa e política sem considerar, desde o início, como afirma Judith Butler, que somos "em algum sentido, seres linguísticos, seres que requerem linguagem para ser?" (1997, p. 1). O que a autora procura enfatizar com essa afirmação é que somos constituídos enquanto sujeitos e adquirimos inteligibilidade discursiva - ao menos nos arranjos políticos contemporâneos — dentro dos termos oferecidos na linguagem, que nos precede e condiciona a partir de uma temporalidade e uma espacialidade próprias. Somos vulneráveis à linguagem, que nos forma continuamente, nos afetando e restringindo, mas também viabilizando a ação e a crítica, seu alargamento e até mesmo sua revisão. Determinados modos de pertencimento, soberania e sujeição são inaugurados e negociados em regimes discursivos, cujos termos delimitam as propriedades da palavra. As narrativas literárias, por si só comprometidas com o princípio estético de indeterminação das identidades e igualdade temática que caracteriza a modernidade (RANCIÈRE, 2014), constituem em si mesmas recortes ordenados da experiência, configurações específicas do sensível que propõem formas de existência orientadas. Nesse sentido, por causarem efeitos naqueles que entram em contato com elas, podem oportunizar novas possibilidades de subjetivação.

Sob esse viés, alguns textos parecem, em dado momento, contexto ou projeto, mais produtivos que outros, talvez por dialogarem e responderem de maneira mais instigante às solicitações de determinada conjuntura, ou por produzirem outras sensibilidades ao manifestarem um dano e provocarem uma desidentificação (RANCIÈRE, 2014) entre os sujeitos e as posições a eles disponibilizadas. As relações entre política e narrativa, portanto, vão muito além do dialógico: não se trata de pensar a política como uma temática que a literatura aborda e problematiza, nem de supor que a política instrumentaliza a literatura como um meio para fins determinados. Conforme insistiu exaustivamente Jacques Rancière ao longo de sua obra, o campo da produção literária e da percepção política não são distintos, nem se capturam um ao outro estrategicamente; ao contrário, estão imbricados pelo simples fato de que, na base da política, há sempre uma estética, um regime de visibilidades que organiza a experiência. A literatura, ao redispor os corpos e seus sentidos, intervém na distribuição dos 
espaços e dos tempos, do que se vê e do que se diz e do que se pode dizer sobre o que é dito e visto (RANCIÈRE, 2015) - o que é outra maneira de dizer que ela faz política.

Em sua maioria, as obras de Scholastique Mukasonga são narradas em primeira pessoa e navegam os nexos entre a narrativa individual e a nacional, entre tribulações particulares e os conflitos étnico-políticos na Ruanda do século XX, entre o sujeito e as condições de sua possibilidade. A autora retraça os limites entre a vida privada e cotidiana, com seus momentos de felicidade familiar e solidariedade comunitária, e as turbulências públicas da nação, com as perseguições sofridas por sua família e seus vizinhos. Esses aspectos se apresentam de maneira singular em A mulher de pés descalços (2017a [2008]), livro no qual Mukasonga ocupa-se de contar a história de sua mãe, Stefania, vítima do genocídio tutsi de 1994. Se, por um lado, deparamo-nos com uma narrativa que relembra, através de uma descrição objetiva, os desafios de uma mãe para proteger seus filhos da violência, da fome e do desterro, por outro encontramos, também, um tom de luto e denúncia, cujo requerimento sincero é que essas perdas sejam registradas e pranteadas.

No presente artigo, buscamos refletir acerca dos insights que $A$ mulher de pés descalços pode oferecer às discussões sobre narrativa, política e ética no âmbito da crítica literária. Estamos interessados em analisar de que maneira a reivindicação do rito fúnebre — do qual as famílias devastadas pelo massacre foram destituídas - enquadra e, nessa operação, descontinua os marcos de reconhecimento que circunscrevem as vidas tutsis como inelutáveis (BUTLER, 2015). Acreditamos que a narrativa de Mukasonga é política no sentido rancièreano do termo: manifesta um dano e redistribui a partilha do sensível (RANCIÈRE, 2014; 2015), fazendo falar quem antes não tinha voz, ou não tinha voz neste regime específico de visibilidades, no qual uma tutsi não é considerada cidadã e, portanto, não possui legitimidade para relatar-se ruandesa. Além disso, gostaríamos de investigar como a problemática de dar um relato de $s i^{1}$ a partir da história da mãe faz emergir uma série de opacidades na própria voz narrativa, as quais então se proliferam, exigindo que o relato exceda a descrição do sujeito e, assim, indagando a respeito das condições de possibilidade de sua formação. Em outras palavras, para contar a história de Stefania, é necessário contar a história — ou melhor, narrar a experiência localizada - de uma nação em frangalhos, de um conflito étnico irresolúvel e, por fim, de um genocídio menosprezado. Por fim, examinamos de que modo esse relato poderia redesenhar os contornos de uma história nacional ao desafiar e romper com certos

\footnotetext{
${ }^{1}$ Por relato de si, entendemos a resposta ética a uma demanda por responsabilidade que excede o escopo da dinâmica punitiva nietzschiana, conforme propõe Butler em Relatar a si mesmo (2017).
} 
enquadramentos epistemológicos que restringem as respostas emotivas e a comoção pública frente à perda de vidas que não foram reconhecidas como dignas de serem preservadas e lamentadas.

\section{Um compromisso estético-político}

Ruanda se encontra no coração da África, tendo sido colônia do Império Alemão antes de, logo após a Primeira Guerra, ser entregue à Bélgica sob o auspício da Igreja Católica. Em 1962, através de um referendo, tornou-se independente, e assim foi declarada a República de Ruanda. As tensões entre as etnias hutus e tutsis são antigas e datam de séculos; no entanto, é a partir do período colonial e da consequente República que estas assumem características modernas de perseguição sistemática e extermínio, especialmente sob influência de agentes externos ao conflito (POTTIER, 2002). Scholastique Mukasonga nasceu em 1956, em um momento em que as perseguições, expurgos e agressões contra a etnia tutsi rumavam a uma escalada assustadora, a qual culminaria no genocídio de 1994. Com Nossa do Senhora do Nilo (2017b), romance originalmente publicado em 2012 e que encerra sua chamada trilogia autobiográfica, a autora reconstrói, através de um relato polifônico, a ascensão das hostilidades que antecederam o golpe de estado de 1973. Vemos como esse contexto de promoção de violência contra tutsis ganha força à medida que cresce, também, a narrativa sócio-política dos hutus enquanto povo majoritário, detentores legítimos do poder e dos meios de reprodução da cultura, do direito à palavra, ao território e ao controle de ambos.

Em seu ensaio para a revista The New Yorker intitulado Grief, a autora questiona a seletividade da palavra "genocídio", aparentemente séria demais para ser usada para descrever massacres étnicos na África. Como se exigisse uma certa elaboração intelectual, uma tentativa de compreensão de um evento através de um termo complexo, que não seria aplicável à violência "primitiva" lá praticada, a comunidade científica ocidental se exime de utilizá-la quando as tragédias se passam longe dos grandes centros econômicos. O genocídio perpetrado em 1994 em Ruanda, embora reconhecido internacionalmente, não possui nem de longe o peso semântico, político e cultural da Shoá, o paradigma teórico para se pensar a catástrofe humana no século XX. Contudo, não há dúvidas de que retém as devidas profundidade e importância; o que diferencia este de outros episódios posicionados no eixo do pensamento sócio-político é o enquadramento discursivo operando e moldando sua apreensão e recepção, segundo o qual 
vidas negras e africanas não causam o mesmo grau de comoção que vidas brancas e do Norte Global.

Mukasonga possui um status particular em relação ao episódio: se, por um lado, ela é certamente uma sobrevivente, não é de forma simples que esse aspecto se configura. A autora não estava em Ruanda quando o massacre - que durou alguns meses e deixou entre 500.000 e 2.000.000 vítimas tutsis ${ }^{2}$ - eclodiu, porém ela não apenas experienciou décadas de violência física e moral, que guiaram e restringiram sua trajetória, como perdeu quase toda a sua família, brutalmente assassinada em 1994. Sua infância, conforme narrada em seus livros, é marcada pelo terror e pelo exílio, transcorrendo em parte na província de Bugesera, em um campo de refugiados e sob condições de extrema precariedade (induzida por um governo hutu de cunho eugenista), e em parte em Kigali, no liceu Notre-Dame-de-Citeaux, no qual foi aceita através de um programa de cotas. Posteriormente, à medida que avançam as animosidades do conflito, ela é forçada a se exilar no Burundi, onde passou a trabalhar com serviço social para a UNICEF (MUKASONGA, 2017a; 2018).

A mulher de pés descalços é o segundo volume do que é considerado pela própria autora (LUCAS, 2020) como a sua trilogia autobiográfica, baseada principalmente em sua vida em Ruanda. A autora sugere um trânsito entre testemunho e ficcionalização, articulando vivências particulares e experiências coletivas à elaboração de fabulações sensíveis. Nesse livro, ela oferece um tributo à sua mãe e às outras mulheres da comunidade, que lutaram para criar seus filhos e preservar sua cultura, mas, infeliz e inevitavelmente, pereceram no genocídio. É definitivamente em torno das mulheres que a narrativa se centra: através de uma prosa descritiva, a narradora retrata os papéis de gênero e seu impacto na divisão do trabalho na sociedade tutsi, a sororidade e o espírito comunitário incentivados por Stefania nos fundos do $i n z u^{3}$, altercando entre a preservação da tradição e um certo distanciamento crítico quando esta se revela prejudicial para a comunidade ${ }^{4}$.

A narrativa de Mukasonga é fragmentada: não há uma cronologia explícita ou uma lógica causal entre os capítulos, e cada episódio contado nos leva a conhecer um costume ou

\footnotetext{
${ }^{2}$ As estimativas, segundo Guichaoua (2020), podem variar de acordo com a metodologia em questão. É oportuno lembrar que o próprio questionamento do número pode facilmente assumir um caráter violento.

${ }^{3} \mathrm{O}$ inzu, palavra, de acordo com a autora, sem tradução adequada para o francês, é uma casa pequena, feita de palha trançada, onde as mães de família gozam de prestígio e autonomia, aprimorando seus usos específicos.

${ }^{4}$ Um episódio que bem ilustra essa questão é o estupro de Viviane: ao invés de relegar a moça à tradicional quarentena exigida pela tradição, Stefania e as outras mulheres cuidam de suas feridas e ajudam-na a dar à luz o filho bastardo na casa da família. Para afastar a maldição, não se expulsou, como previa o costume, a mulher corrompida e seu filho; ao contrário, ambos passaram por um ritual de purificação com as águas sagradas da nascente do Rwakibirizi.
} 
uma norma da vida tutsi, sempre atravessados pela relação que Stefania estabelece entre o hábito em questão e o que uma situação em particular impõe. Seja a assimilação fiel das incursões missionárias católicas (o próprio nome de batismo da autora, "Scholastique", é um reflexo da catequização ruandesa), seja o terror das perseguições e as estratégias desenvolvidas para saná-lo, Stefania é descrita como uma guia, revelando um sujeito que constantemente negocia identificações contraditórias e antagonistas:

Ela agradeceu a Virgem Maria e também a Ryangombe, o mestre dos Espíritos. Apesar de boa cristã, mamãe dizia que não se podia rejeitar ninguém, e menos ainda o Deus dos ancestrais: "É preciso capinar todo o sorgo, repetia ela, pois nunca sabemos qual vai dar primeiro". Como ela não sabia que fora uma dádiva de Maria ou de Ryangombe, era melhor se conciliar com os dois (MUKASONGA, p. 107, 2017a).

Conflitos entre identificações e filiações são centrais para compreender a obra de Mukasonga, apresentando-se em diferentes âmbitos da vida e servindo como uma das fundações críticas de sua escrita. No trecho, Stefania nos revela um dos principais, isto é, o confronto entre a religião católica branca e as crenças tradicionais, o qual jamais é resolvido, permanecendo em constante negociação e deliberação e conservando um cunho ambíguo ao longo do texto. É, em parte, a partir da recorrência desses conflitos que podemos observar o conteúdo mobilizador de um conjunto de importantes afetos políticos, como a indignação, a culpa, a saudade e o luto, revelando a elaboração de uma perturbação em sua escrita.

Apesar da base autobiográfica, não devemos esquecer que Scholastique se considera uma contadora de histórias (LUCAS, 2020); ou seja, há um trabalho estético sempre em curso estruturando suas obras. Essa particularidade apresenta uma espécie de problema, no sentido butleriano, quanto à diferenciação do objeto da crítica, isto é, de quem se está falando, se da Mukasonga autora, ou da Mukasonga narradora, já que ambas respondem ao mesmo nome. Problemas, para Butler (2007), não precisam sempre assumir um caráter negativo: se são inevitáveis, nossa tarefa pode ser explorar o que eles exprimem e as possibilidades que eles produzem. Ainda que optemos por utilizar Mukasonga e o termo "autora" para nos referimos a elementos extradiegéticos e "narradora" para elementos diegéticos, há um grau de indistinguibilidade entre ambas, na medida em que se trata de uma autoficção, obra permeada e, inclusive, inaugurada e encerrada por uma voz assumidamente autoral, que se anuncia no início e no fim:

Ela não nos chamava pelos nomes de batismo, Jeanne, Julienne, Scholastique, e sim pelos nomes de verdade, que tinham sido escolhidos por nosso pai [...]: "Umubyeyi, Uwamubyirura, Mukasonga!"' (MUKASONGA, 2017a, p. 5) 
Eu gostaria de perguntar: "Para onde vão vocês crianças? [sic] Por que não voltam para casa?", mas eu sei qual é a resposta, pois estou no meio das meninas, eu, Mukasonga, vou caminhando ao lado de Cândida, minha amiga [...]. (MUKASONGA, 2017a, p. 155)

De maneira alguma isso significa que suas narrativas se opõem à verdade, mas, isto sim, que a verdade é contada por meio de um compromisso epistemológico literário. A verdade comunicada pela obra de arte percorre seus próprios caminhos; ainda que a era da "soberania estética da literatura" (RANCIÈRE, 2015) tenha revogado a linha divisória entre ficção e testemunho, entre a razão dos fatos e a razão das histórias, unindo-as sob um mesmo regime de verdade, o poético demonstra (e depende dos) sentidos latentes das coisas — não o seu "em si”, mas a sua potência-de-ser.

\section{Custos do reconhecimento: crítica e ambiguidades}

"Mãezinha, eu não estava lá para cobrir o seu corpo, e tenho apenas palavras palavras de uma língua que você não entendia — para realizar aquilo que você me pediu. E estou sozinha com minhas pobres palavras e com minhas frases, na página do caderno, tecendo e retecendo a mortalha do seu corpo ausente." (MUKASONGA, 2017a, p. 7)

É com essa frase crua e pungente que Scholastique Mukasonga encerra as páginas inaugurais de $A$ mulher de pés descalços. Envolver com panos o corpo materno era um rito fúnebre crucial em Ruanda, uma exigência que Stefania fazia questão de relembrar às filhas sempre que podia: a elas caberia esconder seu cadáver do olhar alheio, não só para resguardálo, mas para salvar a si mesmas de um assombramento eterno. No entanto, "perdidos na pestilência da vala comum do genocídio" (MUKASONGA, 2017a, p. 7), seus restos mortais acabaram desassistidos, desabrigados do escárnio dos assassinos e da fome dos cachorros e hienas. A falta de comoção por sua perda lembra a noção butleriana de vida inelutável (BUTLER, 2015), isto é, que não é digna de ser pranteada e, portanto, de ser protegida. Para a filósofa, ser passível de luto é pressuposto para toda vida valorável, pois é justamente em virtude desse pesar futuro que se preserva e mantém uma vida, procurando minimizar ao máximo sua precariedade constitutiva.

Ainda que todo corpo seja vulnerável por princípio, estando sempre à mercê dos outros — de espaços, temporalidades e sociabilidades específicas a limitar sua autonomia —, há formas de dominação, instituídas por marcos de reconhecimento, que se instauram e garantem que determinados corpos sejam mais vulneráveis, mais exploráveis e destrutíveis em comparação a outros. Os esquemas de inteligibilidade que produzem esses marcos estabelecem 
uma série de normas, termos e convenções cuja atualidade molda um ser vivo em sujeito, conferindo-lhe apoio e condições possibilitadoras para que seja de fato uma vida enlutável. O problema epistemológico da apreensão de uma vida, diretamente ligado ao problema ontológico da produção normativa de uma vida, deságua no problema ético da definição do que é uma vida e de como reconhecê-la. Central ao pensamento político contemporâneo, a categoria hegeliana de reconhecimento, interpretada e elaborada por Butler $(2015$; 2017), fornece um vocabulário produtivo para compreender o que está sendo articulado por Mukasonga, tanto num âmbito intersubjetivo como político. Reconhecimento, nesse quadro teórico, permite que reflitamos sobre ambiguidades no relato de formação do sujeito, no que concerne tanto à sua dependência primária de uma sociabilidade, quanto ao caráter violento que pode assumir ao constituir sua entrada na ontologia social.

No regime político da Ruanda do século $\mathrm{XX}$, os membros da etnia tutsi não são reconhecidos enquanto cidadãos de primeira classe, ou sujeitos de direito, na medida em que estão fora da proteção do Estado concedida aos integrantes da nação, e mecanismos básicos de participação e anteparo civil (como a liberdade de ir e vir, o protesto, a isonomia e a segurança pública) lhe são negados. Ao contrário, eles são apreendidos como seres abjetos, animalescos, insignificantes - inyenzis, conforme foram apelidados, quer dizer "baratas", daí o título da obra de estreia de Mukasonga. Embora tenham sua existência ratificada e façam parte do tecido social, veem-se constantemente despidos de sua humanidade em função da segregação socioeconômica e da violência estatal de que são vítimas. Além disso, a imposição do exílio e, consequentemente, de uma vida marginalizada garante que, no enquadramento discursivo que constitui a comunidade imaginária da nação, eles percam a distinção da individualidade, as idiossincrasias e sensibilidades que conferem ao sujeito a capacidade de ser legível como um rosto humano (BUTLER, 2017). Se não há diferenciação entre indivíduos e o grupo ao qual pertencem, também não há injúrias cometidas contra seres humanos, apenas investidas, consideradas totalmente plausíveis, contra uma mesma entidade homogênea e, portanto, desprovida de sentimentos.

Recuperando as primeiras linhas deste artigo quanto à constituição do sujeito dentro dos termos da linguagem, ser interpelado é, precisamente, uma das maneiras pelas quais essa constituição ocorre. No entanto, se essa interpelação assume um caráter injurioso, o processo de sujeição em curso explora e abusa de uma vulnerabilidade primária a fim de assegurar a si próprio, instaurando uma hierarquia de dominação. A alcunha inyenzis não é apenas uma ofensa, mas um modo de interpelação específico, cuja intenção é marcar uma diferenciação e 
uma subordinação ontológicas (BUTLER, 1997). Procedimentos de desumanização, que se traduzem tanto em atos de perseguição quanto de preconceito (a exemplo da ridicularização dos traços físicos e dos costumes), são fundamentais para a legitimação de agressões e assassinatos, pois somente vidas desprezíveis, que não importam, podem ser aniquiladas sem punição ou reveses:

\begin{abstract}
Os militares do campo de Gako, assentados entre os vilarejos e a fronteira próxima ao Burundi, estavam ali para lembrar aos tutsis que eles não eram mais seres humanos, e sim inyenzis, baratas, e que era permitido e justo persegui-los e, no fim, exterminá-los. (MUKASONGA, 2017a, p. 9. Grifo nosso.)
\end{abstract}

Antigamente, dizia Stefania, “em Ruanda”, a gente podia ir a um cercado a outro por meio do bananal. [...] Em Gitagata, ninguém tinha coragem de levar a vizinha até a porta de casa. Todo mundo temia um encontro desagradável na estrada: com jovens do partido, com militares. [...] "Somos prisioneiras", suspirava mamãe. (MUKASONGA, 2017a, p. 132-133. Grifo nosso.)

A menção a um passado digno irrecuperável e à destituição do estatuto de sujeito pleno indica, também, a interrupção, senão extinção, de devires possíveis. Deparamo-nos, ao longo do texto, com a elaboração de um luto não só por familiares e amigos mortos ou caídos em desgraça, pela Ruanda de outrora e pela antiga sensação de pertencimento, mas também por uma série de possibilidades ontológicas doravante negadas - por exemplo, o sentimento nobre da maternidade, o orgulho por uma prole composta de muitos filhos homens e a valorização da educação ${ }^{5}$. Quando se perde certas cenas interpelativas, como a reunião com outras mulheres para fumar cachimbo e a limpeza intestinal das crianças com umubirizi, perde-se certos modos de subjetivação, certas trajetórias subjetivas.

Trazer a noção de vida inelutável não implica alegar que as perdas tutsis não foram jamais registradas nem pranteadas: a impunidade aqui mencionada refere-se, sobretudo, aos perpetradores das violências e àqueles que delas foram cúmplices, para quem não eram perdas em absoluto porque não havia, ali, vida reconhecida para ser perdida. Trata-se, ao contrário, de marcar a imprescindibilidade da construção de uma narrativa específica de Ruanda enquanto um Estado-nação hutu — ou no qual o povo hutu, sendo o povo majoritário, possui direitos soberanos - para a marginalização e bloqueio da agência tutsi, cuja consequência extrema é o seu extermínio.

\footnotetext{
${ }^{5} \mathrm{~A}$ honra de ter filhos homens era usurpada às mães tutsis pelo medo constante de perdê-los, mais sujeitos que estavam à morte por assassinato. Já o acesso à educação, ainda que valorável e desejável, podia rapidamente tornarse um risco: "Saber escrever era algo perigoso se você tinha um pai exilado em Burundi. Logo começam a suspeitar que você está se correspondendo com os tutsis que preparam seu retorno da Ruanda, que você é uma espiã dando informações aos que estão desse lado da fronteira e poderia facilitar a volta dos tutsis." (MUKASONGA, 2017a, p. 21).
} 
Lentamente, os dois militares pegaram as espingardas. "Eles não miravam no coração, repetia minha mãe, e sim nos seios, somente nos seios. Eles queriam dizer a nós, mulheres tutsis: "Não deem vida a mais ninguém, pois, na verdade, se colocarem mais alguém no mundo, vocês vão acabar trazendo a morte. Vocês não são mais portadores de vida, são portadoras de morte”. (MUKASONGA, 2017a, p. 22. Grifo nosso.)

Isso envolve a pressuposição de uma ideia de comunidade política como eminentemente nacional, isto é, baseada em modos nacionais de pertença, e da nação como unívoca e uniforme, correlata ao estado, o qual, por sua vez, nela encontra seu fundamento. Daí a insistência em banir minorias nacionais: o constitucionalismo permite que se instrumentalize critérios de cidadania para confinar, exilar ou controlar um povo, porém o prisma do "político" não se refere unicamente à filiação e à participação em um estado de direito. Há, conforme sugere Butler, “formas não-nacionais de oposição política" (BUTLER, 2018, p. 44) que podem ser danosas e eficazes.

Através de seus escritos, Mukasonga opõe esse recorte ordenado do sensível a outro, ao seu próprio, revelando-nos outro modo de pertencimento possível — um que, talvez, aproximese do contranacionalismo. O reconhecimento, no sentido hegeliano de uma intersubjetividade que precede e condiciona a própria subjetividade (e a reflexividade), passa ao largo do poder organizado e de seu sistema de legitimação, sendo, ao contrário, conferido no seio da comunidade, entre tutsis:

\begin{abstract}
A caca do bebê, amarela como a dos pardais, se chamava ubunyano e era importante não só pelos laços que estabelecia entre mãe e filho, mas entre o recém nascido e as outras crianças do vilarejo. Ubunyano era também o nome da festa que celebrava, depois do nascimento do bebê, a primeira vez que ele saía de casa. [...] As crianças entendiam confusamente que provar o ubunyano do recém-chegado era um gesto de acolhimento, de reconhecimento dele como um irmão que deveríamos proteger, ajudar a crescer e ensinar a fugir das ameaças mortais que pensariam sobre nós. Afinal, tinha tido o azar de ser, como nós, um tutsi. (MUKASONGA, 2017a, p. 67-69)
\end{abstract}

Aprendemos, ainda, que, no espaço protegido do inzu, nos momentos de segurança, toda perda era registrada e lamentada: o que é negado é o pranto público, a demonstração de que uma vida vivida foi perdida e que, portanto, deveria ter sido passível de preservação. Essa modalidade de luto é perigosa, pois é capaz de perturbar, através da sensibilidade coletiva, a ordem e a hierarquia, transformando o espaço do comum, rompendo com o enquadramento epistemológico que estrutura o reconhecimento e expondo sua seletividade supressora. Conforme sugere Butler (2006, p. 38), “a proibição de certas formas de luto constitui por si só a esfera pública”, o que implica dizer que a supremacia do estado hutu depende do apagamento 
desses corpos do espaço comum, de que seus nomes não sejam pronunciados nem relembrados no pranto (daí inyenzis, baratas), tornando a violência contra eles "desrealizada e difusa".

Uma vez que tal prática lhe foi interditada, é apenas através da manifestação poética, da reformulação das impressões e marcas do real em materialidade estética, que Mukasonga pode cobrir o corpo de sua mãe, fazendo do seu relato a proteção que lhe foi negada. Contar sua história é, em certa medida, um imperativo, um dever, pois representa a tentativa de cumprir, retroativamente, uma promessa já perdida. Contra o silêncio da indiferença e do esquecimento, a autora oferece suas memórias, as "pobres palavras" e frases que elaborou nesta língua estrangeira onde enfim encontrou abrigo. Sua relação com o francês é, nesse sentido, ambígua, atravessada por contradições da herança colonial. Em entrevista à The White Review (LUCAS, 2020), ela comenta a coexistência de ambos os idiomas em sua mente: se, em função de sua experiência escolar em um país catequizado, o francês representa a língua escrita, letrada, o kinyarwanda é a língua materna em todos os sentidos — falada nas ruas e em casa, porém, e sobretudo, por sua mãe, a quem a autora, quando escreve, imagina segurando sua caneta ou se inclinando sobre o computador.

Há uma interessante contradição simbólica aqui em jogo: o pano literário tecido por Mukasonga para proteger sua família da violência do abandono é composto de palavras incompreensíveis a qualquer um sobre quem se fala. $\mathrm{Ou}$, dito de outro modo, a língua que se ocupa de transformar em monumento as vivências de um povo silenciado é estrangeira e inacessível a esse mesmo povo. É a língua dos brancos, daqueles que vieram contar outras histórias, "histórias que não eram nossas, que não eram contadas em volta do fogo [...] histórias cheias de ódio, de morte" (MUKASONGA, 2017a, p. 123). O que ela opera é um ato linguístico de apropriação, explorando e ocupando, justamente, a modalidade de linguagem que lhe foi negada - a que pode demarcar e cristalizar, através de uma narrativa recorrente, a história de uma nação e os que dela fazem parte. Numa ressignificação da palavra que embaralha os termos da partilha do sensível, a autora, fazendo uso de uma língua estrangeira (e, portanto, ao mesmo tempo imposta e vedada), reclama para si um espaço no comum, questionando e interrompendo a ordem de dominação que despiu os tutsis do direito à paridade de participação na vida pública ruandesa.

Butler e Spivak (2018, p. 7), em um diálogo crítico publicado em livro e intitulado Quem canta o Estado-nação?, cunharam essa expressão com base no emblemático episódio de 2006 em Los Angeles, quando o hino estadunidense foi cantado em espanhol por residentes ilegais, o que deu margem para questionamentos sobre quem pode "reivindicar o direito aos direitos? 
Quem pode cantar e se apropriar do hino que representa emblematicamente o Estado-nação?”. Gostaríamos de nos valer dessa mesma expressão, de maneira livre, para nos referirmos à operação estético-política realizada por Mukasonga: com a língua que lhe é possível, ela "canta" outra Ruanda em suas narrativas, reivindicando para si e os seus — sobretudo sua mãe, cujos comportamentos e práticas são, conforme comprova ao longo da narrativa, os de uma verdadeira mãe de família - o estatuto de ruandesa. O âmbito não é mais o do hino nacional, evidentemente, mas nos parece análoga essa "contradição performativa" (BUTLER, 2018, p. 13) que procura produzir seu pertencimento, ou conquistá-lo pelo dissenso.

Quando Mukasonga conta suas histórias, sua família, seus afetos e sua cultura, ela invoca o coro daqueles que, como ela, foram destituídos do direito a ter direitos: ela não "canta" sozinha, sua força vinculativa vem do legado citacional de sua reivindicação, ecoando, atualizando e recontextualizando demandas anteriores (BUTLER, 1997). Seu canto é resistência não somente por ela não ocupar o lugar de quem está autorizado a pleitear e exigir remissões, mas porque ela não "canta" dentro dos termos exigidos pelo estado de Ruanda para conceder-lhe reconhecimento. Ela não pede, não solicita, mas reivindica o reconhecimento ao imprimir, de forma não-violenta, uma marca na nação, afirmando, por meio da interpelação literária, que as perdas tutsis são passíveis de luto. O "canto" de Mukasonga excede as categorias do reconhecível e tem o potencial de alargar os termos do reconhecimento, alterando, mesmo que momentaneamente, a esfera do aparecimento, visto que, a cada encontro com seus textos, a cada linha lida, seus clamores são reanimados e nos interpelam a reconhecer sua perda.

\section{Um relato que excede o "eu”}

Em A mulher de pés descalços (MUKASONGA, 2017a, p. 7), a narrativa apresenta uma focalização em primeira pessoa e, portanto, há um si-mesmo contido naquele eu que narra, que afirma "eu não estava lá para cobrir o seu corpo" (grifo nosso). Esse eu claramente não é autopoiético, não é uma criação ex nihilo, mas emerge mediante um assujeitamento a certas normas (ou termos para reconhecibilidade) que o precedem e excedem. Nossa argumentação vem expondo que essa narradora estabelece uma relação ambígua e crítica com a norma e os requisitos da inteligibilidade; no entanto, devemos questionar que eu é esse que "canta" um outro tipo de pertencimento, o qual, ao mesmo tempo que luta por um reconhecimento, também desafia a legitimidade de seus termos. 
Esse questionamento revela outra dimensão no texto de Mukasonga, que estabelece um vínculo incisivo entre estética, política e ética. O elemento ético se expressa em uma atitude bem particular, reiterada por esse eu que narra e denuncia: há a aceitação de uma instância de perda de controle de si, uma espécie de consciência dos limites do que pode ser relatado a partir dessa perspectiva em primeira pessoa, do que esse sujeito pode conhecer de si e do outro. Butler (2017, p. 32) argumenta que a compreensão dessa opacidade indissolúvel não autoriza o sujeito a "fazer o que quer ou a ignorar suas obrigações para com os outros" — pelo contrário, revela uma relacionalidade primária com o outro, o cenário de uma responsabilidade ética que emerge do enigmático e do desconhecido. A atitude ética está em abraçar essa opacidade do outro no eu, essa alteridade no coração do eu. Nesse sentido, há, evidentemente, um limite do que pode ser reconstruído narrativamente por um eu, o qual precisa sair de si, hesitar e falhar para narrar aquilo que, de modo ambivalente, não é totalmente seu nem apenas do outro.

Esse aspecto se materializa quando a narradora começa, tentativamente, a relatar a si mesma, assumindo o lugar central do quadro: “Já vi, algumas vezes, descreverem as mulheres tutsis como donas de casa que tinham por única ocupação trançar cestinhos inúteis ou mexer a batedeira distraidamente sobre a perna esticada" (MUKASONGA, 2017, p. 41, grifo nosso). Esse relato inicia uma cena ética, mas ainda não sabemos quem é o outro que a anima e, assim, faz uma interpelação - e poderíamos, inclusive, argumentar que esse outro é inventado, é aquele que acolhe, pela leitura, a reivindicação da narrativa (BUTLER, 2017). Em seguida, porém, observamos que a narradora abdica desse lugar central, deixando o primeiro plano; o self narrativo encontra seu limite e deve ceder a uma opacidade irredutível que toma o controle, expondo os limites da cognoscibilidade do eu. É por essa razão que falar em relato de si não é tanto fazer menção a um gênero literário quanto a uma operação lógica que assume uma forma narrativa para dar conta da responsabilidade ética diante de uma interpelação — contar uma história sobre si não é o mesmo que dar um relato de si. Trata-se de um ato performativo de revelar o si-mesmo, entregando-se "a um modo público de aparição" (BUTLER, 2017, p. 147); de dar sua verdade e a condição social dessa verdade sem supor, no entanto, uma compreensão absoluta desse processo e de sua temporalidade, nem que se é a sua origem.

Nesses instantes de confronto com as limitações da coerência do nosso relato, do conhecimento de si, presenciamos o encontro com o outro, uma relação que joga o eu para fora de si mesmo e da qual não há retorno: a partir daí, o eu segue transformado pelos encontros que experienciou e experiencia. Na narrativa, isso se traduz em um gesto retórico distinto e constante da narradora, a qual, para dar um relato de si, precisa abdicar da posição inicial de 
protagonista. Há um desejo por reconhecer o outro, mas também esse desejo encontra seus limites, pois o que é reconhecido não é exatamente o "ponto de vista" do outro, e sim a própria opacidade compartilhada, um desconhecimento comum (BUTLER, 2017).

No mesmo parágrafo, a narradora continua: "sempre $v i$ minha mãe com a enxada na mão revirando a terra, semeando, capinando e colhendo, isso antes do nosso exílio, em Gikongoro, em Magi ou, por força maior, em Nyamata, nos vilarejos dos deportados" (MUKASONGA, 2017a, p. 41, grifo nosso). O relato, que se inicia no eu pela conjugação do verbo "ver", já é marcado por um movimento de despossessão: esse sujeito abraça os laços sociais pelos quais é formado, dos quais depende e aos quais é eticamente obrigado (ATHANASIOU; BUTLER, 2017). Seu lugar é cedido rapidamente a Stefania, quem pode dar continuidade ao relato, trazendo a experiência da mulher tutsi trabalhadora e resistente que contradiz a falsa acepção de que teria "por única ocupação trançar cestinhos inúteis" (MUKASONGA, 2017a, p. 41). Para falar de si, a narradora precisa inevitavelmente falar de sua mãe; no entanto, ela não tenta desvendar ${ }^{6}$ esse outro, mas, ao contrário, descobre que Stefania também possui uma dimensão inescrutável. Há, inclusive, uma condição para a ação aqui narrada - assinalada pela expressão "por força maior" —, relembrando-nos de que a história dedicada a narrar Stefania encontra igualmente um limite e transpõe-se para a exterioridade do registro social do trabalho:

Acontece que, em Ruanda, os trabalhos no campo nunca terminam. Se tivesse que encontrar um começo para aquilo que não tem começo nem fim, diria que esses trabalhos começam com as primeiras chuvas de outubro, quando se planta feijão e milho. [...] As ruandesas como Stefania, e como as de hoje em dia, sejam elas hutus ou tutsis, não dedicam todo o tempo a trançar esses delicados cestinhos que ficam uns dentro dos outros e que, muitas vezes, são vistos pelos turistas como a atividade principal da mulher ruandesa (MUKASONGA, 2017a, p. 41-42).

O que emerge nesse ponto crítico não é uma tentativa de reconstruir as origens da autorreflexão, tornando nítida a opacidade compartilhada entre a narradora e sua mãe através de uma narração sobre as pré-condições do próprio relato - uma temporalidade inacessível, já que, estritamente falando, segundo afirma Butler (2017, p. 55), "não posso estar presente numa temporalidade que precede minha própria capacidade de autorreflexão, e qualquer história que eu possa dar sobre mim tem de levar em consideração essa incomensurabilidade constitutiva". Longe disso, a narradora recusa a fantasia da coerência e a transparência do sujeito e recorre à

\footnotetext{
${ }^{6}$ No sentido de que oferecer um relato único de sua mãe — enquanto uma mãe tutsi sofredora, por exemplo — implicaria transformá-la em objeto transparente, ou seja, recusando sua opacidade primária, fechando seu horizonte de possibilidades existenciais.
} 
temporalidade idiossincrática do trabalho na terra e das plantações, que passa a ser o sujeito narrado. $\mathrm{O}$ artifício retórico usado impossibilita retraçar a origem do relato, sublinhando os entrelaçamentos entre o si-mesmo, o outro e a norma. Esse vínculo entre a temporalidade in media res, e que não possui nem começo nem fim, do relato de si e a vida no campo reforça que o sujeito sempre emerge enquanto tal numa cena que o precede, que o relato por ele dado já se insere em uma cena iniciada antes de sua chegada, a qual não se pode recuperar plenamente.

Algumas linhas adiante, a narradora descreve o papel simbólico e material do sorgo: " $\mathrm{O}$ sorgo, sim, era um ruandês legítimo. A terra era para ele o seu próprio inzu.” (MUKASONGA, 2017a, p. 42). Para explicitar a importância da planta, fonte de alimento e de dignidade para o povo tutsi, uma memória significativa é evocada: "Foi trabalhando nas plantações de sorgo que mamãe me ensinou muitas coisas sobre Ruanda de antigamente.” (MUKASONGA, 2017a, p. 44). Nesse sentido, o sorgo funciona como um resquício de respeitabilidade; símbolo da legitimidade ruandesa - e, portanto, de uma adscrição interditada à narradora e por ela reivindicada - , ele mantém uma temporalidade outra, ou penetra a temporalidade do exílio e da escassez. Parece haver, simultaneamente, um retorno em direção ao relato de si: falar de si e de sua infância, de sua mãe e do inzu, da comunidade e das relações sociais, de Ruanda e de sua história ambivalente deságua em falar do sorgo. Há uma complementaridade entre sorgo e memória, como se compartilhassem uma opacidade entre si. Esta permanece irresolúvel — não significa, de modo algum, que o movimento retórico devolve coerência e harmonia à narração —, mas atesta que o relato é produzido performativamente nessa lacuna crítica. Compreendido dessa maneira, o relato de si oferecido na obra projeta-se sempre como dependente de um outro, tanto no sentido de um tu concreto, como de um Tu investido de uma futuridade promissora, ou "da dimensão social da normatividade que governa a cena de reconhecimento" (BUTLER, 2017, p. 36).

Enquanto corolário desse movimento vinculativo entre o relato de si e a experiência tutsi, o sorgo também parece estabelecer uma relação constitutiva entre o relato da narradora e a questão de quem pode narrar (ou "cantar") o Estado-nação. Ao inscrever o sorgo em seu relato, ela imprime também, reversamente, sua marca no sorgo: o sorgo emerge somente sob a condição de uma opacidade, ou seja, aqueles que o plantam a ele estão inevitavelmente ligados. Se, para relatar a si mesma, ela precisa recorrer à temporalidade da terra e à planta-símbolo da legitimidade ruandesa, seu relato está indiscutivelmente unido ao relato de Ruanda, que, por sua vez, requer o movimento inverso. 
Consoante Butler (2017, p. 61), "Se a identidade que dizemos ser não nos captura e marca imediatamente um excesso [...], qualquer esforço de 'fazer um relato de si mesmo' terá de fracassar para que chegue perto de ser verdade". A narradora não recusa as lacunas de seu relato e, desse modo, permite que o outro assuma seu lugar de alteridade, em movimento, irresolvível, vivo, aquilo que excede o que pode ser relatado: "Se deixar o outro viver faz parte da definição ética do reconhecimento, tal definição será baseada mais na apreensão dos limites epistêmicos do que no conhecimento" (BUTLER, 2017, p. 61). Deixar o outro viver implica, aqui, deixá-lo "em aberto", incoerente, singular mesmo se parte inconteste de uma categoria de sujeitos. Stefania é "mantida viva", ou "feita reviver" — ou talvez simplesmente "coberta" por esta mortalha literária, cuja responsabilidade é a rememoração — também porque a narradora a registra em sua multiplicidade: quando comete erros em relação ao casamento de seu primogênito, quando solicita em segredo calcinhas de algodão à filha, quando vai contra a tradição ou a modifica. Ao mesmo tempo que é a mulher de família tutsi por excelência, Stefania é ela própria, com seus enigmas primários e imperscrutáveis; sua humanização, ou constituição em humanidade, dá-se, por consequência, na contramão dos processos de homogeneização defendidos pela lógica genocida, dado que sua identidade se desdobra em posições e agenciamentos diversos.

Esse gesto de deslocamento do eu se alarga e estende ao longo da narrativa, seja quando a narradora traz a memória dos dedos de sua mãe passeando carinhosamente entre seus cabelos procurando piolhos, ou quando discorre sobre o valor incontestável da vaca para a comunidade tutsi. A atitude é discreta, por vezes imperceptível; por outras, redesenha e até apaga, explicitamente, os limites entre o que pertence à narradora e o que pertence ao outro ou à norma. Por não se tratar de uma conduta metodológica, como uma repetição idêntica do mesmo artifício retórico, nem sempre ela assume a mesma forma ou possui a mesma intenção, e seus efeitos podem ser inesperados, sentidos e interpretados de maneiras que ultrapassam as intenções originais.

\section{Considerações finais}

Estamos sempre narrando, ou pelo menos utilizando, às vezes precariamente, estruturas e procedimentos narrativos para tornar nossas experiências inteligíveis. Isso não significa que sua inteligibilidade se torne transparente, sem hesitações nem espaço para a incompreensão; tal objetivo seria não apenas inalcançável, mas, como viemos defendendo, violento, pois 
reestabeleceria a fantasia de um sujeito fixo, cristalizado, autossuficiente, que se relaciona reflexivamente apenas consigo mesmo e ignora uma relacionalidade inescapável e primária, sem jamais perguntar "Quem é esse tu que reside em mim, do qual não consigo me separar?" (BUTLER, 2017, p. 106). A proposta ética aqui retrabalhada procura recuperar o vínculo entre a tarefa ética e a formação do sujeito, cuja conclusão é que qualquer princípio de responsabilidade passa pela investigação da vida social, das redes históricas e contingentes que fazem e desfazem o humano, das condições retóricas que possibilitam o dizer. Mas também pela despossessão, pelas impressões por vezes reiteráveis, por vezes irrecuperáveis, que condicionam o presente, pelos riscos aos quais se pode submeter ao recusar determinada reconhecibilidade e ao demandar outras.

Dar um relato de si pode se tornar um imperativo de sobrevivência, tornando pública uma verdade, confissão ou manifestação social, testemunhando em nome de algo e dando algum tipo de voz àqueles que, injustamente, não podem falar — seja porque não estão mais aqui, seja porque não foram autorizados à fala. Nesse contexto, deve-se assumir um compromisso ético com aqueles aos quais se está dando voz, compromisso que se materializa de diferentes maneiras, conforme as demandas da situação em particular — não há um método ou retórica ética a priori produtiva. O compromisso ético da obra de Mukasonga encontra-se, justamente, no acolhimento do desconhecido, no fato de que ela não almeja mapear e explicitar as razões para cada comportamento, cada contravenção, assumindo ser incapaz de conhecer todos os motivos por detrás das ações ao escorregar do seu testemunho, de "contar sua história", em direção a outros registros e temporalidades, ao "relato de si". Sua narrativa assume a responsabilidade de estar, desde o princípio, entregue aos outros, vulnerável a eles.

O modo como isso é apresentado em A mulher de pés descalços é, em parte, consequência dos modos pelos quais nós, leitores, podemos acessar a obra, em função de nossas experiências subjetivas anteriores, as quais formam nossa própria capacidade de experienciar cognitiva e hermeneuticamente o texto. Certamente há outros caminhos para acessar criticamente o livro, através de outras formas de interpelação, ou seja, de sermos interpelados, interrompidos e mobilizados por ele; todavia, assumimos nós, também, um compromisso ético com a obra, que afeta aquilo que pode ser dito sobre e a partir dela. Se estamos trazendo esta leitura possível, é com base nessa relação, igualmente hesitante e defectível, que estabelecemos com o relato que nos é dado - e, quando perguntamos o que pode nos contar, essa pergunta leva em consideração que a resposta é falibilística, contextual e provisória. Deixar-se interpelar por uma obra de arte é, talvez, deixar-se desfazer pelo outro, ser vinculado ao que não se é, 
experimentar um novo modo de subjetivação. Como bem definiu Rancière (2017, p. 109), o fenômeno de literariedade - isto é, quando há "desvio da escrita em relação a ela mesma [...] quando a letra é confrontada ao sentido que ela não contém ou ao espírito que lhe falta" recupera a corporeidade da hermenêutica, a realização de que é pela atualização sempre errante dos sentidos possíveis da leitura que se faz literatura. A letra circula por toda parte, e é precisamente o corpo que "falta à letra", e que vem "suprir essa falta" (RANCIÈRE, 2017, p. 110), que lhe confere verdade, sobrevida, potência.

Mukasonga (aqui talvez marcadamente indistinguível de sua narradora) relata porque, de alguma maneira, é quem pode relatar: a ela foi direcionada uma interpelação que, em princípio, era sumariamente recusada àqueles que não puderam relatar a si mesmos, ou a quem um relato não foi solicitado fora de um regime de contenção e punição. Em outras palavras, se Mukasonga escreve e conta sua história, que é lida e traduzida e passada adiante, ela é reconhecida; de certo modo, passa a preencher determinados requisitos de inteligibilidade de um quadro epistemológico que aqueles que não sobreviveram, aos olhos de quem agora reconhece, não preenchiam. Antes "sem-parte", ela adentra e é incorporada ao comum, reformulado e transformado em função de sua manifestação, de seu desafio à norma, desse desentendimento (RANCIÈRE, 2018). Entrementes, aquela que relata, relata uma indignação, relata perturbando os termos do reconhecimento e relata a partir do desejo de reconhecer. Mukasonga finaliza o livro narrando o pesadelo que ronda suas noites, ficcionalização do medo de que suas palavras não sirvam para enlutar todos os corpos tutsis abandonados sem sepultamento durante o genocídio, de que não consiga honrar o compromisso ético a que se propôs por ainda estar viva: "Você tem um pano grande o suficiente para cobrir todos eles... para cobrir todos... todos...?" (MUKASONGA, 2017a, p. 156). Do outro lado desse diálogo, interpelados pelo texto, procuramos, com a parte que nos cabe, responder à reivindicação da autora; sua experiência, que sobrevive ao perdurar em relato, reverbera em seus efeitos de diferença, produzindo afetos diversos — tristeza, indignação, dor, vergonha, e outros por vir — em nós que a lemos e procuramos dar continuidade a seu apelo.

\section{REFERÊNCIAS}

BUTLER, Judith. Excitable speech: A politics of the performative. Nova Iorque: Routledge, 1997. 
BUTLER, Judith. Relatar a si mesmo: crítica da violência ética. Belo Horizonte: Editora Autêntica, 2017 [2003].

BUTLER, Judith. Precarious Life: the powers of mourning and violence. Londres: Verso, 2006 [2004].

BUTLER, Judith; SPIVAK, Gayatri Chakravorty. Quem canta o Estado-nação? Língua, política, pertencimento. Tradução de Vanderlei J. Zacchi e Sandra Goulart Almeida. Brasília: Editora Universidade de Brasília, 2018 [2007].

BUTLER, Judith. Quadros de Guerra. Quando a vida é passível de luto?. Rio de Janeiro: Civilização Brasileira, 2015 [2009].

BUTLER, Judith. Gender trouble. New York: Routledge Classics, 2007 [1990].

GUICHAOUA, André. Counting the Rwandan Victims of War and Genocide: Concluding Reflections. Journal of Genocide Research, Sydney, v. 22, n. 1, p. 125-141, 2020.

LUCAS, Julian. Interview with Scholastique Mukasonga. Disponível em: https://www.thewhitereview.org/feature/interview-with-scholastique-mukasonga/ . Acesso: em 22 de julho de 2021. Publicada em outubro de 2020.

MUKASONGA, Scholastique. Baratas. Tradução de Marília Garcia. São Paulo: Editora Nós, 2018 [2006].

MUKASONGA, Scholastique. A mulher de pés descalços. Tradução de Marília Garcia. São Paulo: Editora Nós, 2017a [2008].

MUKASONGA, Scholastique. Nossa Senhora do Nilo. Tradução de Marília Garcia. São Paulo: Editora Nós, 2017b [2012].

MUKASONGA, Scholastique. Grief. In: The New Yorker, Publicado na edição de 22 de junho de 2020 nos EUA. Disponível em: https://www.newyorker.com/magazine/2020/06/22/grief . Acesso em: 22 de julho de 2021.

POTTIER, Johan. Re-imagining Rwanda: conflict, survival and disinformation in the late twentieth century. Cambridge: Cambridge University Press, 2002.

RANCIÈRE, Jacques. A partilha do sensível. Estética e política. Tradução de Mônica Costa Netto. São Paulo: Editora 34, 2015.

RANCIÈRE, Jacques. Politicas da escrita. Tradução de Raquel Ramalhete et alii. São Paulo: Editora 34, 2017.

RANCIÈRE, Jacques. Nas margens do político. Tradução de Vanessa Brito e João Pedro Cachopo. Lisboa: KKYM, 2014. 
RANCIÈRE, Jacques. $O$ desentendimento. Política e filosofia. Tradução de Ângela Leite Lopes. São Paulo: Editora 34, 2018.

Artigo submetido em: 05 ago. 2021

Aceito para publicação em: 18 out. 2021

DOI: https://dx.doi.org/10.22456/2238-8915.117465 